\title{
Multiple Cassava Viruses' Co-Infections and Resurgence of Pests Are Leading to Severe Symptoms and Yield Losses on Cassava in the South-Kivu Region, Democratic Republic of Congo
}

\author{
E. B. Bisimwa1', D. R. Birindwa1', M. O. Yomeni², N. Rudahaba², K. Byamungu², \\ C. Bragard ${ }^{3}$
}

${ }^{1}$ Faculté des sciences agronomiques, Université catholique de Bukavu, Bukavu, Democratic Republic of Congo ${ }^{2}$ SARD-SC Project, International Institute of Tropical Agriculture, Bukavu, Democratic Republic of Congo ${ }^{3}$ Applied Microbiology, Phytopathology, Earth and Life Institute, UCLouvain, Louvain-la-Neuve, Belgium Email: ebisimwa@yahoo.com, espoir.bisimwa@ucbukavu.ac.cd, Stephan.winter@jki.bund.de, claude.braga rd@udouvain.be

How to cite this paper: Bisimwa, E.B., Birindwa, D.R., Yomeni, M.O., Rudahaba, N., Byamungu, K. and Bragard, C. (2019) Multiple Cassava Viruses' Co-Infections and Resurgence of Pests Are Leading to Severe Symptoms and Yield Losses on Cassava in the South-Kivu Region, Democratic Republic of Congo. American Journal of Plant Sciences, 10, 1969-1988.

https://doi.org/10.4236/ajps.2019.1011138

Received: January 10, 2019

Accepted: November 12, 2019

Published: November 15, 2019

Copyright $\odot 2019$ by author(s) and Scientific Research Publishing Inc. This work is licensed under the Creative Commons Attribution International License (CC BY 4.0).

http://creativecommons.org/licenses/by/4.0/

\begin{abstract}
A survey was completed during the last five years (2014-2018) to update and assess changes in the cassava pests and diseases occurrence as well as to understand how these changes occur regarding the recent new viruses spread under a climate change context in the South-Kivu region, Democratic Republic of Congo. The eight territories of South-Kivu were surveyed during the rainy seasons from 2015 until 2017 except for Uvira and Fizi where data were recorded in 2018 regarding the prevalence of unstable agro ecological factors which may influence pest and diseases dynamic in these two territories. During the data collection, pests and disease incidence and severity were recorded as well as the sampling of cassava leaves for molecular viruses' detection. The recorded data showed that Cassava mosaic disease (CMD) remains the most encountered disease $(75 \%-80 \%)$ and its vector (the whitefly Bemisia tabaci) the most important pest (10 - 18 adult whiteflies per leaf). The major changes were recorded for Cassava brown streak disease, recently reported in the region, for which a significant increase was recorded, with not reports before 2012 to $70 \%-80 \%$ incidence in 2018 in the Ruzizi plain area (Uvira and Fizi). Molecular detection revealed a coexistence of both two viruses, the cassava brown streak virus (CBSV) and Ugandan cassava brown streak virus (UCBSV) in single and mixed infections. Co-infections cassava mosaic and cassava brown streak diseases were frequently recorded resulting in severe expression
\end{abstract}


leaves' symptoms and tuber yields' losses. Common pests and diseases considered as minor have drastically become serious threat to cassava production by increasing both their incidence and severity values. The cassava bacterial blight (20\%), cassava green mite ( $20 \%-70 \%)$, cassava mealy bugs and cassava grasshoppers were recorded as a great challenge in relation with an occurrence of long dry season resulting in four consecutive dry months without rain. The high occurrence of CBSD on new CMD-resistant varieties has enforced farmers to recover local CMD-susceptible varieties which revealed a relative CBSD-tolerance and moderate yield losses. This need for virus control is really challenging cassava crop in a region where the diseases pressure is high and people consume cassava and its products seven days a week. Research gaps identified in the study are the need for breeding new varieties with tolerance/resistance to both CMD and CBSD viruses as well as the extensive use of rapid multiplex diagnostic tools to ensure early diagnostic and availability of good quality planting material at farmers' level.

\section{Keywords}

Cassava Genotypes, Distribution, Climate Factors, South-Kivu, Re-Emergence, Whitefly

\section{Introduction}

Cassava (Manihot esculenta Crantz, Family Euphorbiaceae) is a staple food for more than $60 \%$ of Sub-Saharan Africa population. It's cultivated for root tubers, leaves and its potential yield under various environments. Mainly consumed as an energetic food, Biocassava program has improved its nutrient content by modern biotechnologies [1]. Africa produces $50 \%$ of the total world production, however, yield and total production remain low. The Democratic Republic of Congo (DRC) is one of the top five world producers where cassava and its derivate products are consumed at least four times a week [2].

Pests and diseases are the most important constraint of cassava production in Africa, with high economic loss impact, sometimes leading to total loss of production [3]. Among them, Cassava mosaic disease (CMD) was mentioned to be the most important in recent years and has been the most documented constraint especially following the spread of the regional pandemic of unusually severe mosaic from Uganda and neighbouring countries. Several authors [4] [5] [6] and [7] [8] have mentioned the prevalence of dual infections of ACMV and EACMV-Ug leading to CMD severe symptoms in South-Kivu and Kisangani regions in DRC.

Until now, CMD is known to be caused by more than eight begomovirus species widely distributed in Sub-Saharan Africa: the African cassava mosaic virus (ACMV) [9] [10], the East African cassava mosaic virus (EACMV) and EACMV-like strains [3] [11]-[17], the East African cassava mosaic Cameroon virus (EACMCV) [18] 
[19], the East African cassava mosaic Malawi virus (EACMMV) [20], the East African cassava mosaic Zanzibar virus (EACMZV) [21], the South African cassava mosaic virus (SACMV) [22] [23] [24], the Indian cassava mosaic virus [25] [26] and the South East African cassava mosaic virus (SEACMV) reported by [27]. Severe CMD symptoms are frequently associated with new virulent species [19] and synergism due to dual infections [18]. Molecular diagnosis on cassava samples collected from DR Congo to diagnose CMD virus species and strains in the two regions (South-Kivu and Kisangani) showed a low diversification among the virus' species independently of the agro-ecosystems in which cassava is grown.

Following its recent spread, Cassava brown streak disease (CBSD) is becoming also a serious threat on cassava in East and Central Africa. It was first reported in Tanzania during the 1930s [28] and was strictly limited to the coastal part of Eastern Africa for a long time [29]. It was then reported in the internal part of the continent during the 2000s-2010s in Mozambique [30] [31], Kenya [32], Burundi [33], Rwanda [34] and Uganda [35]. In D.R. Congo, CBSD was reported for the first time in the North-Kivu province [36] and recently in Ituri [37] but yet documented information is available on its presence in the other cassava growing area like in South-Kivu as well as its recent spread and distribution to support the suspicious CBSV-like symptoms frequently reported in several area of the country.

These two late decades, CMD and CBSD have been the most intensively monitored and documented in many Sub-Saharan Africa countries, strangely relegating other pests and diseases to minor value both in research and funding programs. This resulted in resurgence and changes of occurrence for alternate pest of epidemiological concern. However this confirms that minor biotic constraints can also lead to major effects. [3] mentioned that uncontrolled cassava bacterial blight (CBB) and Cassava anthracnose disease (CAD) were able to occasion complete crop losses under heavy infection on local susceptible genotypes while [38] reported that high yield losses induced by root rots due to Armillaria mellea and Fomes lignosus and foliar spots due to Cercospora sp. (CLS) can be observed in humid forest area.

In Africa, major pests include cassava green mite (CGM), Mononychellus tanajoa, cassava whitefly Bemisia tabaci (CWf) and cassava mealybug (CMB), Phenacoccus manihoti [39]. Grasshoper, Zonocerus variegatus and Pseudotheraptus devastans, are also cited as minor cassava pests [40] [41] [42] [43]. Until now the only one large report on cassava biotic constraints was proposed by [43] but only focused on Rwanda.

Regarding the recent development of climate change effects (temperature elevation, extension of dry seasons and rarefaction of rains), many cassava pests and diseases may change occurrence values and distribution and their interactions with diversified virus diseases complex in a hostile environment may produce severe impact on cassava health, growth and productivity. In this context a large study which provide an updated information on cassava biotic constraints 
in this region with emphasis on the recent CBSD spread is a real need to highlight management approaches to be developed for cassava production sustainability in South-Kivu and consequently in DRC.

\section{Methods}

\subsection{Understanding the Cassava Production and Yield Following the Spread of the Pandemic Severe Cassava Viral Diseases (CMD and CBSD) in DRC}

Cassava production data used were from the [2] database for African countries. Average yield was also calculated referring to cassava production and related cassava fields squares in each area and showed the same tendency as the production evolution.

\subsection{Field Data Collection during the Survey}

The two steps of the survey were undertaken in the Sud-Kivu province, Eastern DR Congo, in the major cassava growing area during the rainy seasons: First, in 2015 covering all the eight territories of South-Kivu (KABARE, WALUNGU, KALEHE, IDJWI, UVIRA, FIZI and MWENGA) but due to its difficult accessibility and insecure issues only few information was collected in SHABUNDA (Figure 1). The selected area is covering three agro-ecological zones which can easily be splited up regarding the characteristics. The first one is a tropical zone in low altitude (climate type $A_{1-3}$, altitude $<$ to $1000 \mathrm{~m}$, rainfall $<1300$ $\mathrm{mm}$ /year, annual mean temperature $>24^{\circ} \mathrm{C}$ ) including several villages in Ruzizi plain and Fizi coastal area. The covered villages for this region are for example Luvungi, Sange, Kiliba, Mboko, Swima, Sebele and Nyiemba, Mwenga is also part of this group. The second, considered as a tropical zone in mid-altitude (climate type $\mathrm{Aw}_{3}$, altitude $1000-1400 \mathrm{~m}$, rainfall > $1300 \mathrm{~mm}$ /year, annual mean temperature $20^{\circ} \mathrm{C}-23^{\circ} \mathrm{C}$ ) include the territory of Kalehe and some villages of Kabare and Walungu. The third, also a tropical zone in high altitude (climate type $\mathrm{Cw}$, altitude $>1400 \mathrm{~m}$, Rainfall $>1300 \mathrm{~mm} /$ year, annual mean temperature $12^{\circ} \mathrm{C}-19^{\circ} \mathrm{C}$ ) include Walungu, Kabare and Idjwi territories. In mid and high altitude, clay soils are predominant while in low altitude; sandy soils with alluvial deposits are predominant. Environment and agro-ecological characteristics were expected to influence cassava pests and diseases occurrence and their distribution [44].

In each village, ten fields with less than six months old were monitored and cassava plants health was recorded along the two diagonals of the field. All cultivated cassava genotypes in each area were noted. CMD, CBSD, CAD, cassava green mite and mealy bugs damage data (incidence, severity, cutting-borne infection and whitefly infection) as well as the whitefly abundance and other pests data were recorded for each observed plant. Pests and diseases incidences were determined as a percentage of diseased or damaged plants while severity scores were recorded from a 1 - 5 scale as proposed by [45] and used by [46] [47] [48] 


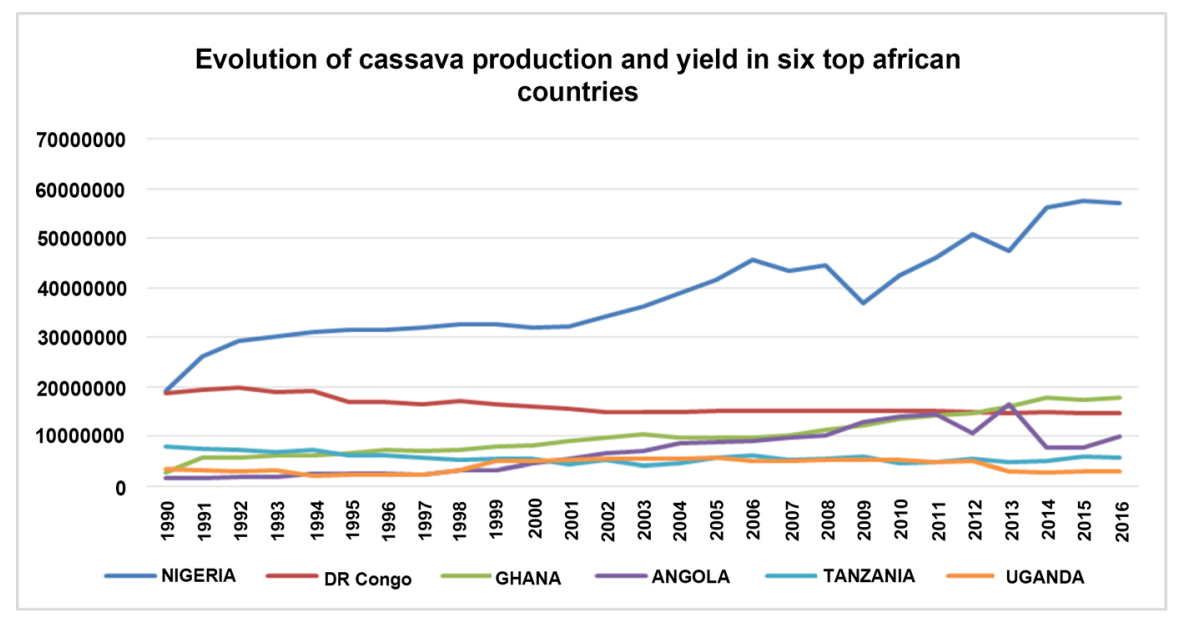

Figure 1. Evolution of cassava production and average yields of top six African countries $\left(\times 10^{6} \mathrm{~T}\right)$. Cassava yield of African countries were calculated as a report of cassava production and cultivated surfaces. Except for Nigeria and Ghana, it can clearly show that since 2010-2011, all East and Central Africa countries are showing production decrease probably caused by an uncontrolled spread of CBSD epidemic occurring since that period. It coincides with the period the CBSD spread was reported with high epidemic pressure. However the Angola CBSD occurrence is yet documented to be related to its cassava production decrease. Related to FAO data, Nigeria and Ghana have reported a significant increase of cassava production and are actually leading the top African cassava producers.

and [49] where 1 is recorded for a healthy plant with no disease symptoms or pest damage and 5 for a severely diseased or damaged plant. Pests' populations, especially whitefly were estimated as a mean whitefly number per leaf on the five top cassava leaves while grasshoppers, Zonocerus sp. and Pseudotheraptus were approximately encountered per plant and then per field. Suspicion of cutting-borne infection was recorded for a cassava plant with CMD or CBSD symptoms on all the plant leaves while whitefly infection was recorded when only upper new leaves were diseased [46].

Second, in 2018, only CBSD survey was monitored in Uvira and Fizi to document epidemiologic data changes occurred this period and to understand how farmers are facing the CMD and CBSD control challenge. Incidence and severity were recorded on each cultivated variety as well as the average yield and yield losses induced to diseased plants.

\subsection{Sampling of Cassava Brown Streak Diseased Leaves and Molecular Diagnostics}

Molecular diagnostic for presence of cassava brown streak viruses was performed on CBSD symptomatic leaves collected on CBS-diseased plants within all the surveyed area but only samples from the Ruzizi plain (Uvira and Fizi) presented the characteristic symptoms of CBSD (yellow chlorosis along the foliar veins and over the whole leaf surface of young and old leaves). Collected samples were then sent to the DSMZ laboratory in Germany where CBSD associated viruses were diagnosed by RT-PCR appropriated protocols as described in [48] 
and [49]. Characteristics symptoms were then described associated to single or multiple infections due to CMVs or CBSVs.

\subsection{Data Analysis}

Collected data were averaged to obtain means for each parameter (incidence, severity score and insect numbers). For incidence calculation we recorded all plants (diseased and no diseased plants) while severity score average was calculated considering only diseased or damaged plants. The statistical analysis was performed by the general analysis of variance using Genstat discovery edition 3 (http://www.vsni.co.uk/) and $\mathrm{R}$ console softwares. Additionally, multivariate analysis (XLSTAT2011) was performed using correlation analysis between pests and diseases prevalence and climate variables.

\section{Results}

\subsection{Evolution of Cassava Production in the Top Six African Cassava Producers Countries}

The evolution of cassava production in African countries [2] including DRC is presented on Figure 2.

Africa produces $50 \%$ of the world cassava production. Nigeria and DRC were the two major producers in Africa and contribute to $50 \%$ of the African production. In 1990, the two countries equally produced $18 \mathrm{MT}$ a year, but two decades later, Nigeria production is $45 \mathrm{MT}$ whereas it is only $15 \mathrm{MT}$ for DR Congo (Figure 2). During this period, the DRC did not veritably profit from IITA and other cassava research networks to improve its cassava production and yields.

Following the spread of the severe CMD, cassava yield decreased from $8 \mathrm{~T} / \mathrm{Ha}$ to less than $6 \mathrm{~T} / \mathrm{Ha}$ in Uganda during the period 1993 to 1998. In Kenya and Tanzania, the pandemy has been reported late and cassava yield decrease has been observed since 1997 for six years. In Rwanda and Burundi, its effect on yield is observed since 2002/2003 regarding the EACMV-UG diagnosis in this country [48]. A light cassava yield decrease is observed in Nigeria around 1997. In contrast, cassava yield in DRC showed an apparent stability around $8 \mathrm{~T} / \mathrm{Ha}$, whereas cassava situation in the South-Kivu province is closed to Rwanda and Burundi tendency, yield decrease is observed since 2002 and maintained until 2006. After this period only cassava yield in DR Congo didn't progress within the top African producers group.

Following the yield decrease period in those different countries, cassava improved and resistant genotypes have been deployed and are mentioned to be the important achievement to cassava yield increase observed in 1999 in Uganda, 2004 in Kenya and Tanzania, 2005 in Rwanda and Burundi and 2008 in the DRC South-Kivu province. However, while diffused genotypes can potentially produce more than $30 \mathrm{~T} / \mathrm{Ha}$, cassava yield remains low probably due to environment and no adapted practices in various cassava growing area (emergence of new diseases and change in common diseases statement, no pest management 


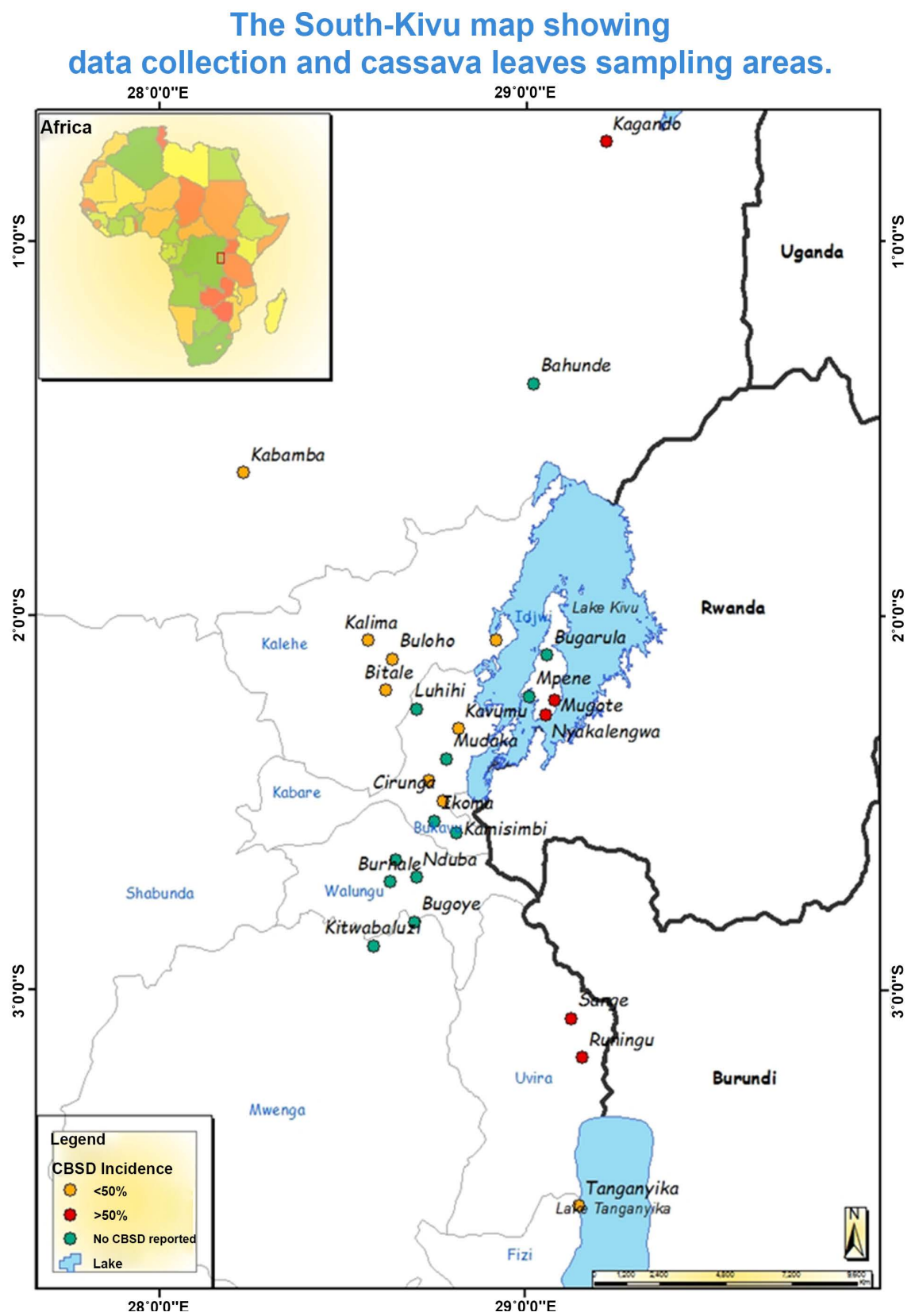

Figure 2. The covered area of this study and incidence values reported during the survey.

strategies, no adapted climatic conditions especially drought, poor soils combined with no use of fertilizers). The slow variety release of CMD-resistant material and the farmers' resistance to abandon their local preferred varieties are responsible of cassava low yield record.

Following the CMD pandemic control mitigation (1990-2010), while cassava production was recovering in most of ECA countries, CBSD spread from the East African coastal countries started to be reported in many interne zones of the continent. The cassava production showed to have been seriously impacted and started to decrease until 2016 (Figure 1) and probably continuously until now. The DRC, has subsequently lost its second place due to ineffective CMD 
and CBSD control strategies, and relegated to the third place by Ghana despite the high cassava production potential

\subsection{Occurrence and Distribution of Cassava Diseases and Pests in the Surveyed Area}

Cassava pests and diseases' recorded data during the survey are presented in Table 1.

\subsubsection{Cassava Mosaic Disease and Cassava Brown Streak Co-Infections}

Cassava mosaic disease is the largely distributed cassava disease in all cassava growing areas of South-Kivu, its incidence varied from $38.4 \%$ at Kalehe to $65 \%$ at Uvira and severity score from 1.5 at Fizi to 2.8 at Idjwi. The highest incidence and severity score values were recorded for villages located in low altitude with more than $24^{\circ} \mathrm{C}$ of temperature (Uvira and Bunyakiri) whereas in mild and high altitude locations with less than $24^{\circ} \mathrm{C}$ of temperature (Katana, Lwiro, Kavumu, Mudaka, Mushweshwe, Birava, Walungu and Nyangezi), incidence and severity score were low. Kalehe, even if located in mid and high altitude, has presented a specific case with high CMD pressure mainly because of the predominance and intensive cultivation of local CMD-susceptible landraces "Nambiyombiyo" and M'Bailo highly appreciated by farmers. In all the surveyed sites, mixed cassava local varieties were predominant and severely CMD-diseased while less than $50 \%$ of farmer's cassava fields have new improved CMD-resistant varieties and CMD-symptoms free. Local varieties "Nambiyombiyo", "M’Bailo", "M’meana", "Cizinduka" and "Pharmakina" were predominant in high altitude whereas "Naunde" and "Nakarasi" were predominant in low altitude. Curiously, no common local varieties were simultaneously recorded in the two altitude agro-ecosystems suggesting that no varieties' exchange occurred. It was also been reported that the most cultivated varieties in the Ruzizi plain were also recorded in neighboring villages in Rwanda (Bugarama) and Burundi (Cibitoke) to illustrate the intensive exchange of planting material between farmers of the three neighboring countries within the same agro-ecological zones [43], Maguruginkware is one of the cultivated variety in Uvira which is originated from Burundi and highly represented in villages near the border.

The molecular diagnostic of CBSV on collected leaves' samples confirmed the CBSD presence in the South-Kivu area not yet reported before. The CBSVs-like symptoms occurrence in different villages is presented in Figure 2 where each location is colored referring to the disease presence or not and its incidence value.

The results of the molecular diagnostic showed a positive tests and detected both presence of Cassava brown streak virus (CBSV) and Ugandan cassava brown streak virus (UCBSV) in single and mixed infections (Figure 3). CBSV was the most predominant in single infection (42.8\%) followed by UCBSV presence in single infection (28.5\%) and dual infection CBSV-UCBSV (7.1\%) while $14.2 \%$ of samples didn't reveal any CBSVs presence probably due to low 


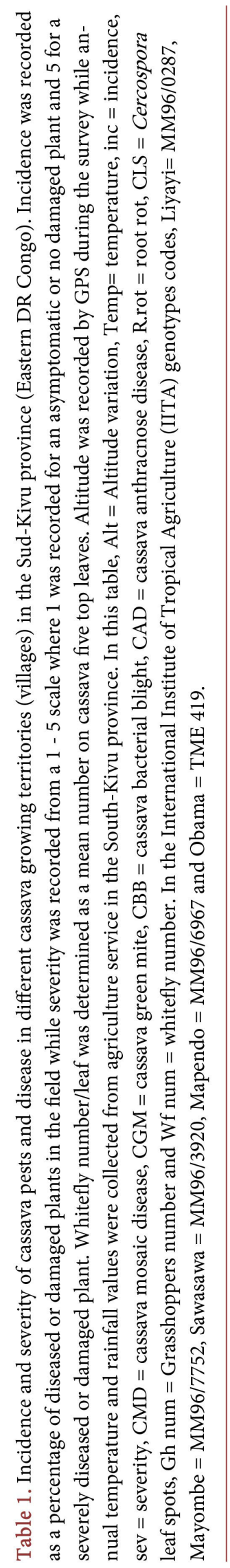

\begin{tabular}{|c|c|c|c|c|c|c|c|c|}
\hline 岁夏 & 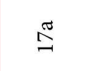 & f & के & $f$ & $\stackrel{\ddot{\Xi}}{=}$ & 胥 & ले & สู \\
\hline $\begin{array}{l}\text { 署 } \\
\text { 苞 }\end{array}$ & $\begin{array}{l}0 \\
0 \\
+1 \\
+1 \\
0 \\
0\end{array}$ & 0 & $\stackrel{\circ}{\circ}$ & 0 & $\stackrel{+1}{0}$ & $\rightarrow$ & ○ & ? \\
\hline త్రું & $\Xi$ & - & - & $\stackrel{\text { in }}{\rightarrow}$ & - & 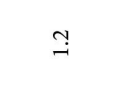 & - & $\exists$ \\
\hline 厌 & in & $\circ$ & 0 & $\hat{n}$ & $\circ$ & $\hat{\curvearrowright}$ & 0 & $\stackrel{i}{\dot{m}}$ \\
\hline 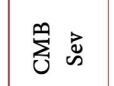 & $\exists$ & - & - & - & - & $\exists$ & $\exists$ & - \\
\hline$\overbrace{0}^{0}$ & $\stackrel{n}{+}$ & $\circ$ & $\stackrel{\circ}{\longrightarrow}$ & $\stackrel{\sim}{i}$ & $\circ$ & $\stackrel{m}{n}$ & กู & $m$ \\
\hline 马् & - & $ت$ & - & $\stackrel{m}{\rightarrow}$ & - & $\stackrel{n}{\rightarrow}$ & $\vec{i}$ & $\stackrel{?}{\longrightarrow}$ \\
\hline \begin{tabular}{l}
\multicolumn{5}{c}{} \\
3 \\
3 \\
0
\end{tabular} & $\stackrel{\circ}{\circ}$ & $\stackrel{8}{6}$ & $\stackrel{0}{0}$ & $\begin{array}{l}\hat{\sigma} \\
\stackrel{6}{6}\end{array}$ & $\circ$ & 芯 & 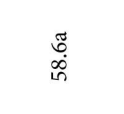 & 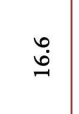 \\
\hline 产 岂 & 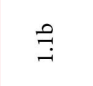 & $=$ & $=$ & $=$ & $\Rightarrow$ & $\stackrel{\overbrace{}}{\rightarrow}$ & $=$ & - \\
\hline 晜怘 & $\begin{array}{l}\vec{\infty} \\
\dot{\infty}\end{array}$ & $\stackrel{\vec{m}}{i}$ & $\stackrel{f}{\circ}$ & 㑒 & $\stackrel{\overbrace{}}{\stackrel{i}{-}}$ & 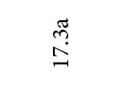 & $\circ$ & $\vec{i}$ \\
\hline ซิ & $\stackrel{0}{\rightarrow}$ & 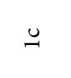 & $\underline{\sim}$ & 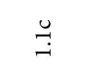 & $\stackrel{\overbrace ّ}{\stackrel{乛}{ت}}$ & $\stackrel{f}{\sharp}$ & $\underline{-}$ & 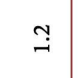 \\
\hline ๑ิ & $\stackrel{\text { }}{\text { ते }}$ & 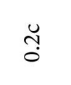 & $\stackrel{u}{a}$ & 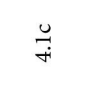 & 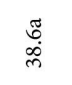 & $\stackrel{\vec{H}}{\vec{i}}$ & $\breve{g}$ & $\hat{a}$ \\
\hline 商 & $\stackrel{\text { తิ }}{3}$ & त્త్ & $=$ & 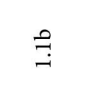 & $\Rightarrow$ & $\stackrel{\sim}{\sim}$ & $=$ & $\stackrel{\Upsilon}{]}$ \\
\hline 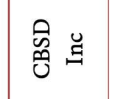 & $\stackrel{\overrightarrow{0}}{\underline{j}}$ & त̆ & 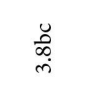 & 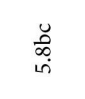 & $\circ$ & ช్ల్ & $\stackrel{4}{0}$ & $\stackrel{\infty}{\alpha}$ \\
\hline 密灾 & $=$ & $=$ & $=$ & $\Rightarrow$ & $\Rightarrow$ & $\stackrel{\widetilde{I}}{-}$ & $=$ & - \\
\hline 㞯 乌 & f & $\circ$ & ถุ̊ & $\stackrel{\text { సి }}{\text { in }}$ & $\circ$ & 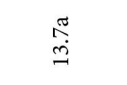 & तิ & $\vec{i}$ \\
\hline 密 & $\stackrel{\breve{h}}{\rightarrow}$ & $\underset{\infty}{\stackrel{\infty}{i}}$ & 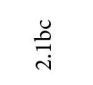 & $\breve{g}$ & $\underset{\stackrel{\tilde{\sigma}}{i}}{\stackrel{0}{i}}$ & $\stackrel{\breve{a}}{\stackrel{\vec{u}}{i}}$ & $\stackrel{\breve{~}}{\vec{i}}$ & $\stackrel{\sim}{i}$ \\
\hline $\begin{array}{l}\breve{\Xi} \\
\stackrel{\Xi}{0}\end{array}$ & 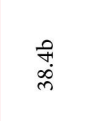 & 苋 & 胥 & $\begin{array}{l}\stackrel{0}{\overrightarrow{7}} \\
\overrightarrow{7}\end{array}$ & $\begin{array}{l}\overrightarrow{\tilde{m}} \\
\text { b } \\
i\end{array}$ & in & 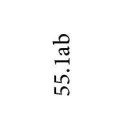 & ஷ̊․ \\
\hline 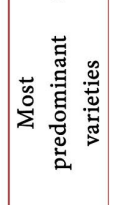 & 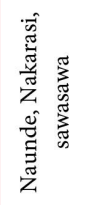 & 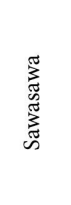 & 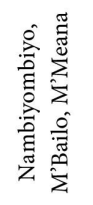 & 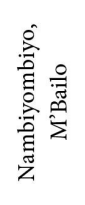 & 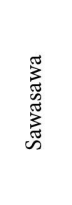 & 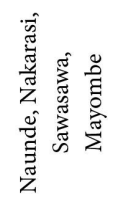 & 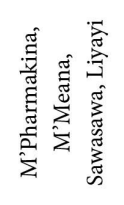 & \\
\hline 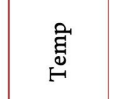 & $\begin{array}{l}0 \\
\stackrel{\Delta}{\wedge}\end{array}$ & $\begin{array}{l}u \\
\dot{U} \\
\dot{V}\end{array}$ & $\begin{array}{l}u \\
\dot{d} \\
\dot{v}\end{array}$ & $\begin{array}{l}0 \\
\stackrel{\vec{V}}{V}\end{array}$ & $\begin{array}{l}\dot{U} \\
\stackrel{\Delta}{x}\end{array}$ & $\underset{\stackrel{0}{\sim}}{\stackrel{0}{\wedge}}$ & $\begin{array}{l}\cup \\
\stackrel{\Xi}{J}\end{array}$ & \\
\hline $\begin{array}{l}\text { 鸟 } \\
\text { 䘮 }\end{array}$ & 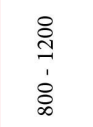 & 字 & 字 & 离 & まू่ & ळे & 容 & \\
\hline 苛 & 空 & 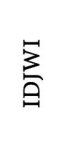 & 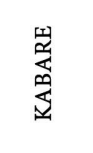 & 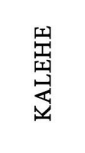 & 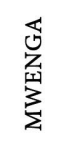 & 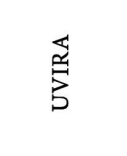 & $\begin{array}{l}2 \\
0 \\
2 \\
0 \\
3 \\
3\end{array}$ & 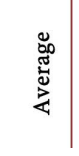 \\
\hline
\end{tabular}




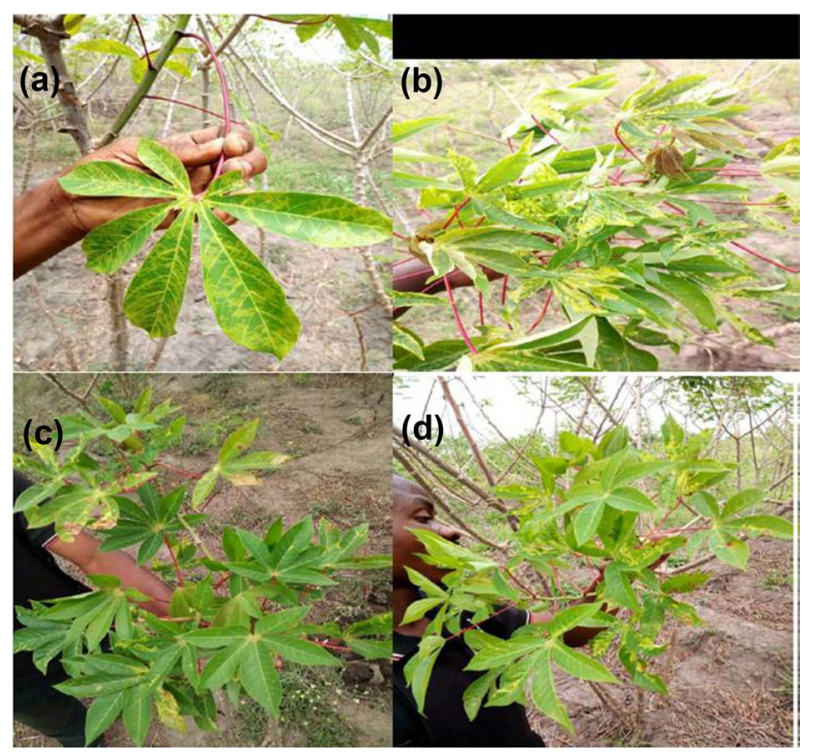

Figure 3. Cassava diseased leaves showing CBSVs symptoms (a), CBSVs + CMVs (b), CBSVs + CBB (c) and CMD alone (d): moderate symptoms were recorded for a single infection while severe symptoms were associated to dual or multiple infections.

virus concentration in samples or insensitive detection methods as well as the defective quality of samples due to a long material process which may have affected its quality.

CBSVs severe symptoms were frequently recorded on CMD-resistant varieties recently released in the South-Kivu region especially Sawa Sawa which is actually the most cultivated improved variety while Liyayi, Clone 1661, RAV (Obama or TME 19) and Mayombe were recorded with moderate CBSVs symptoms, assuming low CBSVs susceptibility. Equally, moderate symptoms were also frequently recorded on CBSVs-infected local varieties plants of Korengo, Mvulamingi, Naunde and Nakarasi.

During the survey it was also observed that unusual severe symptoms on leaves were recorded on dual CMVs-CBSVs infected plants than when only one virus group was present on cassava plant independently of the variety (Figure 3): CBSVs associated to CMVS diseased plants symptoms were the most severe followed by CMVs diseased plants and CBSVs diseased plants were less severely attacked.

\subsubsection{Cassava Bacterial Blight and Cassava Anthracnose and Other Cassava Diseases}

Cassava bacterial blight (CBB) incidence was ranged from less than $1 \%$ in Idjwi, Kabare, Kalehe and Walungu to more than twenty percents in Fizi (21.2\%), Uvira (21.4\%) and Mwenga (38.6\%). Low severity values were recorded in the covered area. The difference of altitude between the agro-ecosystems didn't affect the CBB data and its distribution, yet CBB was frequently observed on improved variety than on local ones. Compared to the situation twenty years ago, 
CBB occurrence has notably changed and can be kept on touch as a major constraint on cassava production in the near future if no attention is focused on it.

Cassava anthracnose disease was less frequent cassava diseases with $0.2 \%$ to $4 \%$ of incidence and severity score low (1.2) except for Uvira where it was recorded with average incidence value of $13.7 \%$. No distribution tendency was observed in the surveyed area and no differences reported in relation to the cultivated cassava genotypes.

In the South-Kivu province, except in humid forest (Mwenga and Shabunda) where root rot pathogens are reported, the other villages weren't affected except in case cassava is grown in swampy soils.

\subsubsection{Cassava Pests}

\section{1) Cassava whiteflies}

The mean whiteflies number per leaf was unequally distributed in the surveyed area depending on altitude and temperature average. The great insects number were recorded at low altitude (Mwenga, Fizi and Uvira) varied from 16 to 17.9 insects per leaf compared to less than 5 insects per leaf recorded at high altitude area. Within fields with cassava genotypes mixtures, whiteflies number recorded were high on improved varieties. Altitude and related temperature has significant negative influence on the whiteflies number within the covered area, high insect population is associated to high temperature in low altitude when in high altitude area, the insect number per leaf was reduced as a result of low temperature impact. A positive correlation was observed between whitefly population and infection type, in Uvira and Fizi the great whitefly number induced an increase of whitefly infection (32\%), while in limited whitefly population conditions, cutting-borne infection was predominant $(80 \%)$. These results are related to the Ugandan case where [48] have observed a significant increase of whitefly population in CMD severe epidemic and post epidemic zones. The whitefly abundance in the Ruzizi plain is once again considered as a key factor of CBSVs spread within the region.

\section{2) Cassava green mite}

Cassava green mite damage were observed everywhere cassava was grown and its incidence values varied from $20 \% \pm 1 \%$ to $70 \% \pm 6 \%$ while severity score were low to moderate $(2-2.9)$. Regarding the incidence values and the damage caused to cassava leaves reducing photosynthetic square of leaves, cassava green mite should be considered as the second biotic constraint on cassava in the surveyed area, fortunately its severity was low in many cases. However, its incidence and severity depend on temperature variation.

\section{3) Other pests}

Before 1987, a historic cassava mealybug invasion has been signaled in DRC both in Bas-Congo and Uvira regions and IITA team has proposed a biological control by using its natural enemy identified in Brazil, Epidinocarsis lopezi bugs (Hymenoptera, Encyrtidae). Since the release of this insect, cassava mealybug has been maintained in control for a long time and no significant damages were 
observed for approximately thirty years. Unfortunately, these five last years, CMB damages have been frequently observed in the Uvira region as a result of an abnormal long dry season recorded every year associated to the mealybug resurgence. Irregular CMB damages are frequently observed in mid and high altitude in Walungu, Kabare and Kalehe where it was not reported yet. This resurgence of CMB and its presence in new area where it was not reported yet, is an alert of changes which may probably be caused by a drastic decrease of E. lopezi population unable to control $\mathrm{CMB}$ dynamic accelerated by temperature elevation in this area. However, there is a need to evaluate both the CMB and its natural enemy population and distribution to highlight the need of a new release of E. lopezi in the region.

Grasshoppers (Zonocerus variegatus) adults and larvae were observed in Uvira area with some insects (less than 10) per filed. However, its damage was very severe on cassava plants on which they have been observed. It was observed that cassava fields planted with Sawa Sawa variety were more damaged especially during a long dry season. During this study, individual bugs, Pseudotheraptus devastans, were observed in cassava fields in low population and no severe damages observed. The principal component analysis showed a strong positive correlation between altitude and pests' incidence and severity, in high temperature agro-ecosystems, pests' incidence was high and produced severe damages to plants, while moderate pests' incidence and low impact damages were associated to agro-ecosystems with low and moderate temperatures. The impact on diseases is also positive as vector population abundance can lead to intensive viruses' transmission and probably the virus development in plant will depend on the temperature.

\subsection{Cassava Varieties as Component Key of Pests and Diseases Dynamics and Management}

During the survey, cultivated varieties were also recorded in relation to pests and diseases data to understand the relationships existing between cassava genotypes and pests and diseases dynamics especially for CBSD tolerance. The survey was completed by cassava variety's collection to test their performance in CBSVs high pressure environment in Uvira. Data collected from the trial are summarized in Table 2.

The prevalence of many CMD-susceptible varieties in the surveyed area is considered as one of the most important factor explaining the persistence of cassava mosaic as the most frequent disease on cassava in DRC. Following the Severe cassava mosaic pandemic, improved CMD-resistant varieties were released and widely disseminated in affected area, unfortunately, local CMD-susceptible varieties didn't completely disappear because of farmers' preferences to their quality. First, most of the local varieties are harvested between 12 and 24 months old without developing root rots, thus farmers can, progressively for a year, harvest cassava tubers depending on his household needs. Contrarily, most of the CMD-resistant varieties usually develop root rots when they 
Table 2. Cassava variety trial results showing the local and improved variety yields and yields losses induced by cassava brown disease on tubers yields in high CBSD pressure in Uvira. Local cassava varieties are CMD susceptible, CBSD-tolerant and produce low tuber yields while new improved varieties are recognized to be more productive and CMD-resistant but seriously attacked by CBSD. The Obama improved variety has recorded the most interesting data and low yield losses and can be recommended to farmers.

\begin{tabular}{|c|c|c|c|c|c|c|c|c|c|c|}
\hline \multirow[t]{2}{*}{ Varieties } & \multirow{2}{*}{$\begin{array}{l}\text { Type of } \\
\text { Variety }\end{array}$} & \multicolumn{2}{|c|}{$\begin{array}{l}\text { Tuber Roots } \\
\text { Numbers }\end{array}$} & \multicolumn{2}{|c|}{$\begin{array}{c}\text { Diseased Roots } \\
\text { Numbers }\end{array}$} & \multicolumn{2}{|c|}{$\begin{array}{l}\text { Roots Infection } \\
\text { Rate }\end{array}$} & \multirow{2}{*}{$\begin{array}{c}\text { Estimated } \\
\text { Yield (T/ha) }\end{array}$} & \multirow{2}{*}{$\begin{array}{c}\text { Estimated } \\
\text { Yield Losses } \\
\text { (T/ha) }\end{array}$} & \multirow{2}{*}{$\begin{array}{c}\text { Estimated } \\
\text { Net Yields } \\
(\mathrm{T} / \mathrm{ha})\end{array}$} \\
\hline & & 6 MAP & 8 MAP & 6 MAP & 8 MAP & 6 MAP & 8 MAP & & & \\
\hline Amasi & Local & 1.00 & 4.00 & 0.00 & 0.00 & 0.00 & 0.00 & 10.00 & 0.00 & 10.00 \\
\hline Cibongoyoka & Local & 0.53 & 5.00 & 0.00 & 0.00 & 0.00 & 0.00 & 10.00 & 0.00 & 10.00 \\
\hline Cintalula & Local & 2.17 & 10.00 & 0.00 & 5.00 & 0.00 & 50.00 & 10.00 & 5.00 & 5.00 \\
\hline Dorothea & Local & 2.33 & 2.00 & 0.00 & 0.00 & 0.00 & 0.00 & 0.83 & 0.00 & 0.83 \\
\hline Kabunga & Local & 0.33 & 2.00 & 0.00 & 0.67 & 0.00 & 33.33 & 2.45 & 0.55 & 1.90 \\
\hline Kamegere & Local & 0.33 & 6.00 & 0.00 & 0.00 & 0.00 & 0.00 & 6.40 & 0.00 & 6.40 \\
\hline Kanombe & Local & 1.67 & 6.00 & 0.00 & 4.00 & 0.00 & 66.67 & 9.00 & 5.00 & 4.00 \\
\hline Kanyunyi & Local & 4.33 & 8.00 & 0.00 & 8.00 & 0.00 & 100.00 & 5.00 & 5.00 & 0.00 \\
\hline Korengo & Local & 2.00 & 13.00 & 0.00 & 0.00 & 0.00 & 0.00 & 23.70 & 0.00 & 23.70 \\
\hline Liyayi & Improved & 6.00 & 6.67 & 0.00 & 0.00 & 0.00 & 0.00 & 29.17 & 0.00 & 29.17 \\
\hline Maguruyinkware & $* * *$ & 1.00 & 4.67 & 0.00 & 3.00 & 0.00 & 65.00 & 4.50 & 2.80 & 1.70 \\
\hline Mahungu & Improved & 3.00 & 4.00 & 2.00 & 2.00 & 50.00 & 50.00 & 3.00 & 1.75 & 1.25 \\
\hline Maombi & Local & 5.67 & 8.33 & 0.33 & 5.00 & 6.67 & 60.05 & 18.00 & 10.33 & 7.67 \\
\hline Mayombe & Improved & 1.67 & 2.67 & 0.00 & 2.33 & 0.00 & 91.67 & 3.17 & 2.33 & 0.83 \\
\hline M'Bailo & Local & 1.00 & 3.00 & 0.00 & 0.00 & 0.00 & 0.00 & 2.50 & 0.00 & 2.50 \\
\hline Musimwa & Local & 2.07 & 6.00 & 0.00 & 4.00 & 0.00 & 66.67 & 7.17 & 3.77 & 3.40 \\
\hline Muzungu & Local & 6.00 & 8.00 & 0.00 & 5.00 & 0.00 & 62.50 & 15.00 & 12.50 & 2.50 \\
\hline Mvuama & Improved & 1.67 & 2.67 & 0.00 & 2.33 & 0.00 & 91.67 & 3.17 & 2.33 & 0.83 \\
\hline Nabana & Improved & 2.33 & 1.00 & 0.00 & 0.00 & 0.00 & 0.00 & 2.00 & 0.00 & 2.00 \\
\hline Nabwigoma & Local & 2.00 & 6.00 & 0.00 & 1.00 & 0.00 & 16.67 & 7.50 & 4.00 & 3.50 \\
\hline Nakarasi & Local & 3.00 & 5.00 & 0.00 & 2.00 & 0.00 & 40.00 & 7.67 & 4.50 & 3.17 \\
\hline Nambiyombiyo & Local & 1.83 & 9.00 & 0.00 & 7.33 & 0.00 & 81.48 & 11.00 & 7.33 & 3.67 \\
\hline Namseelwa & Local & 1.67 & 3.00 & 0.67 & 2.00 & 33.33 & 66.67 & 3.13 & 2.18 & 0.95 \\
\hline Naunde & Local & 1.10 & 2.33 & 0.00 & 2.00 & 0.00 & 88.89 & 0.77 & 0.43 & 0.33 \\
\hline Ngoromane & Local & 3.33 & 7.00 & 2.80 & 1.67 & 84.76 & 23.81 & 2.50 & 2.40 & 0.10 \\
\hline Nvulamingi & Local & 6.93 & 11.00 & 0.00 & 3.00 & 0.00 & 27.42 & 29.47 & 3.52 & 25.95 \\
\hline Obama & Improved & 5.17 & 11.00 & 1.00 & 4.00 & 17.78 & 36.36 & 31.83 & 6.17 & 25.67 \\
\hline Papayi & Local & 3.67 & 5.67 & 1.00 & 4.33 & 27.78 & 76.67 & 2.50 & 1.80 & 0.70 \\
\hline Rav & Improved & 2.33 & 4.00 & 0.00 & 0.00 & 0.00 & 0.00 & 10.50 & 0.00 & 10.50 \\
\hline Sawasawa & Improved & 2.67 & 6.00 & 1.07 & 5.00 & 40.44 & 83.33 & 4.67 & 4.18 & 0.48 \\
\hline TMS/1661 & Improved & 3.33 & 3.00 & 0.00 & 2.00 & 0.00 & 66.67 & 1.50 & 1.05 & 0.45 \\
\hline \multicolumn{11}{|l|}{ ANOVA: } \\
\hline $\mathrm{P}$ & & $<0.001$ & $<0.001$ & $<0.001$ & $<0.001$ & $<0.001$ & $<0.001$ & $<0.001$ & $<0.001$ & $<0.001$ \\
\hline LSD; & & 1.331 & 0.618 & 0.500 & 1.000 & 18.99; & 16.97 & 1.565 & 0.942 & 1.251 \\
\hline$C V$ & & $31.4 \%$ & $6.8 \%$ & $97.2 \%$ & $25.9 \%$ & $117.3 \%$ & $25.7 \%$ & $10.8 \%$ & $20.6 \%$ & $12.6 \%$ \\
\hline
\end{tabular}


are harvested after 12 months old, farmers must harvest all his field in a short time and suddenly facing conservation and processing infrastructure challenges. In such context it's difficult for farmers to cover daily food needs in the household for a long time making farmers in hazardous management of household food supply.

Second, most of local CMD-susceptible varieties are highly appreciated by farmers due to their ability to be processed in diverse cassava consumable sub-products. The most of CMD-resistant varieties are recognized to have a good resistance level (no CMD symptoms observed) also they are high productive, but offer a poor quality of cassava sub-products. The improved variety Sawasawa has then been most cultivated due to high quality of cassava flour compared to other new improved varieties and is actually cultivated by more than $80 \%$ of farmers who are cultivating new varieties.

\section{Discussions}

During this study, we tried to analyze cassava production data in DR Congo referring to the CMD and CBSD spread to highlight its impact at the national and local level. It revealed a direct relationship between the low agriculture performance and political instability as well as the development and spread of cassava pests and diseases over the two past decades. Comparing to the other cassava producer top six African countries, DRC is the only African top six countries where cassava production and yield didn't increase during this twenty years period. Insufficient availability of improved cassava genotypes, non-adapted cultural practices, uncontrolled pests and diseases occurrence are probably the major causes. This study showed evident presence of cassava brown streak viruses (both CBSV and UCBSV) recently spread from the coastal zones of East Africa already reported in other countries as well as other regions of DRC. The presence of CBSVs in DRC can be described as a progress spread front from the coastal zones. According to the findings of this study, it was observed that CBSD is progressing more predominantly in the North-South and South-North direction than in East-West direction, probably because of planting material transfer facilities within the region. The simultaneous presence of the two virus species is similar to what was observed in other countries where the disease is already reported [36] [37] and [49] probably depending on the vector movement within the region while planting material transfer crossing countries is low to explain the disease spread.

Regarding pests and diseases occurrence in the South-Kivu region, it has been observed a positive relationship between pest and diseases pressure with local climate environment manly depending on temperature and altitude. Pests and diseases pressures were high when temperature was high in low altitude zones and decreased when temperature was low. The temperature effect was also reported by [50] on whitefly growth and fecundity. He mentioned a significant increase of whitefly fecundity at $24^{\circ} \mathrm{C}$ compared $15^{\circ} \mathrm{C}, 18^{\circ} \mathrm{C}$ and $21^{\circ} \mathrm{C}$. Temperature impact was also mentioned by [43] to increase the insect's number of gen- 
eration per year, to extend the covering area and decrease the effectiveness of insects' natural enemies. Referring to the data collected in this study, the temperature effect can explain abundant whitefly population in South-Kivu villages where temperature is higher than $24^{\circ} \mathrm{C}$ and consequently influence the CMD and CBSD occurrence (incidence and severity scores) as well as driving their rapid spread. CMD and CBSD high severity scores recorded in this study are probably the result of increasing virus concentration in plant tissues which may vary depending on the environment plants are grown. Pests and diseases occurrence changes were recorded not only for whitefly and its transmitted diseases but also for many other pests as a result of favorable conditions for their development and fecundity resulting in more damages caused to plants. Since then, resurgence of many minor pests for example cassava mealy bug, cassava green mite and grasshoppers have become serious cassava threats in Uvira and Fizi rural area and need to be controlled. This resurgence of high pests population have been observed this last five years especially when the dry season goes beyond four months, a common phenomenon result of climate change in the region. According to recent meteorological data collected these recent days, the two dry seasons in the Ruzizi plain have extended by one more month and favor the insects pullulating and their presence in high altitude area where they were not reported yet, as a result of extending the covered zones.

Additionally, agro-ecosystems where environment characteristics are favorable to cassava (moderate or high temperatures, less heavy and fertile soils, moderate year rainfall), local susceptible genotype's intensive cultivation can exacerbate pests and diseases incidence and severity. [51] [52] [53] emphasized the importance of biodiversity and agro-ecosystems stability which have an influence on plant diseases epidemiology. In this way, [7] and [54] showed that cassava intensive cultivation in homogenous environment was a favorable factor to increase CMD pressure. A similar study realized in Rwanda by [43] reported a CMD mean incidence decrease with altitude elevation while CMD severity was independent of this, severe symptoms mainly depend on the genotypes susceptibility and higher virus species pathogenicity. However, increase of the vector population can sometimes lead to CMD incidence and severity as well as whitefly infection increase.

The results of this study highlighted that the maintenance of CMD-susceptible cassava varieties by the farmers was the key factor of CMD high pressure maintenance in the South-Kivu region for a long time. Diseased plants are a permanent reservoir where whiteflies can still acquire and spread CMVs to healthy plants. The recent CBSD high incidence and severity was associated to intensive cultivation of susceptible improved variety "Sawasawa" widely disseminated in the province. At the same time, this diversity maintenance is considered as an adapted response for CBSD impact resilience, while improved varieties are seriously threatened by the CBSVs, farmers relied to local varieties to harvest something and are actually selecting what they will be planting next years. By measuring the impact of CBSVs on variety symptoms expression and yield losses 
evaluation, this study showed that many local varieties are tolerant but still less productive. This situation is offering more chance to improved variety OBAMA (also called TME 419, RAV) CMD-resistant, CBSD-tolerant, drought-tolerant and more productive to be the actually most preferred variety and which is being promoted as the emergency planting material for these near next years while waiting for the results of research investment to develop resistant material to both CMD and CBSD under progress. While using the Obama variety, it will be advisable to harvest at eight to ten months of cassava age as the CBSD impact on root rot is more prevalent after ten months. Thus cassava growers will significantly reduce economic losses and ensure cassava can still playing its food security and cash crop roles.

\section{Conflicts of Interest}

The authors declare no conflicts of interest regarding the publication of this paper.

\section{References}

[1] Sayre, R., Beeching, J.R., Cahoon, E.B., Egesi, C., Fauquet, C.M., Fellman, J., Fregene, M., Gruissem, W., Mallowa, S., Manary, M., Dixon, B.M., Mbanaso, A., Schachtman, D.P., Siritunga, D., Taylor, N., Vanderschuren, H. and Zhang, P. (2011) The Biocassava plus Program: Biofortification of Cassava for Sub-Saharan Africa. Annual Review of Plant Biology, 62, 251-272.

https://doi.org/10.1146/annurev-arplant-042110-103751

[2] FAOSTAT (2016) FAO Database. Food and Agriculture Organization of the United Nations, Rome. http://FAOSTAT.fao.org/site/339/default.aspx

[3] Legg, J.P., Owor, B., Sseruwagi, P. and Ndunguru, J. (2006) Cassava Mosaic Virus Disease in East and Central Africa: Epidemiology and Management of a Regional Pandemic. Advances in Virus Research, 67, 355-418.

https://doi.org/10.1016/S0065-3527(06)67010-3

[4] Bisimwa, B.E., Walangululu, M.J. and Bragard, C. (2012) Occurrence and Distribution of Cassava Geminiviruses Related to Agroecosystems in the Sud-Kivu Province, Democratic Republic of Congo. Asian Journal of Plant Pathology, 6, 1-12. https://doi.org/10.3923/ajppaj.2012.1.12

[5] Bisimwa, B.E., Birindwa, R.D., Walangululu, M.J. and Bragard, C. (2013) Contribution of Cassava-Maize-Common Beans Intercropping System to the Management of Cassava Mosaic Disease and Its Vector. Current Topics in Virology, 11, 31-40.

[6] Bisimwa, B.E., Walangululu, M.J. and Bragard, C. (2015) Cassava Mosaic Disease Yield Loss Assessment under Various Altitude Agro-Ecosystems in the Sud-Kivu Region, Democratic Republic of Congo. Tropicultura, 33, 101-110.

[7] Monde, G. (2010) Epidémiologie, diversité génétique et phylogéographie des virus de la mosaïque africaine du manioc dans la région de Yangambi en République Démocratique du Congo. Thèse de doctorat, Université catholique de Louvain, 181 p.

[8] Monde, G., Walangululu, J., Winter, S. and Bragard, C. (2010) Dual Infection by Cassava Begomoviruses in Two Leguminous Species (Fabaceae) in Yangambi, North-Eastern Democartic Republic of Congo. Archives of Virology, 155, 1865-1869. https://doi.org/10.1007/s00705-010-0772-3 
[9] Hong, Y.G., Robinson, D.J. and Harrison, B.D. (1993) Nucleotide Sequence Evidence for the Occurrence of Three Distinct Whitefly-Transmitted Geminiviruses in Cassava. Journal of General Virology, 74, 2437-2443.

https://doi.org/10.1099/0022-1317-74-11-2437

[10] Swanson, M.M. and Harrison, B.D. (1994) Properties, Relationships and Distribution of Cassava Mosaic Geminiviruses. Tropical Science, 34, 15-25.

[11] Deng, D., Otim Nape, G.W., Sangare, A., Ogwal, S., Beachy, R.N. and Fauquet, C.M. (1997) Presence of a New Virus Closely Associated with Cassava Mosaic Outbreak in Uganda. African Journal of Root and Tuber Crops, 2, 23-28.

[12] Zhou, X., Liu, Y., Calvert, L., Munoz, C., Otim-Nape, G.W., Robinson, D.J. and Harrison, B.D. (1997) Evidence that DNA-A of Geminivirus Associated with Severe Cassava Mosaic Disease in Uganda Has Arisen by Interspecific Recombination. Journal of General Virology, 78, 2101-2111. https://doi.org/10.1099/0022-1317-78-8-2101

[13] Legg, J.P. and Ogwal, S. (1998) Changes in the Incidence of African Cassava Mosaic Virus Disease and the Abundance of Its Whitefly Vector along South-North Transects in Uganda. Journal of Applied Entomology, 122, 169-178. https://doi.org/10.1111/j.1439-0418.1998.tb01480.x

[14] Legg, J.P. and Okao-Okuja, G. (1999) Progress in Diagnosis and Epidemiological Characterization of Cassava Mosaic Geminiviruses in East Africa. 7 th International Plant Virus Epidemiology Symposium, 11-16 April 1999, 74-75.

[15] Legg, J.P., Ndjelassili, F. and Okao Okuja, G. (2003) First Report of Cassava Mosaic Disease and Cassava Mosaic Geminiviruses in Gabon. New Disease Report, British Society of Plant Pathology. https://doi.org/10.1111/j.0032-0862.2004.00972.x

[16] Legg, J.P., French, R., Rogan, D., Okao Okuja, G. and Brown, J.K. (2002) A Distinct, Invasive Bemisia tabaci (Gennadius) (Hemiptera: Sternorrhyncha: Aleyrodidae) Genotype Cluster Is Associated with the Epidemic of Severe Cassava Mosaic Virus Disease in Uganda. Molecular Ecology, 11, 1219-1229. https://doi.org/10.1046/j.1365-294X.2002.01514.x

[17] Legg, J.P. and Fauquet, C.M. (2004) Cassava Mosaic Geminiviruses in Africa. Plant Molecular Biology, 56, 585-599. https://doi.org/10.1007/s11103-004-1651-7

[18] Fondong, V.N., Pita, J.S., Rey, C., Beachy, R.N. and Fauquet, C.M. (2000) Evidence of Synergism between African Cassava Mosaic Virus and the New Double Recombinant Geminivirus Infecting Cassava in Cameroon. Journal of General Virology, 81, 287-297. https://doi.org/10.1099/0022-1317-81-1-287

[19] Ndunguru, J., Legg, J.P., Aveling, T.A.S., Thompson, G. and Fauquet, C.M. (2005) Molecular Biodiversity of Cassava Begomovirus in Tanzania: Evolution of Cassava Geminiviruses in Africa and Evidence for East Africa Being a Center of Diversity of Cassava Geminiviruses. Virology Journal, 2, 21. https://doi.org/10.1186/1743-422X-2-21

[20] Zhou, X., Robinson, D. and Harrison, D.B. (1998) Types of Variation in DNA-A among Isolates of East African Cassava Mosaic Viruses from Kenya, Malawi and Tanzania. Journal of General Virology, 79, 2835-2840. https://doi.org/10.1099/0022-1317-79-11-2835

[21] Maruthi, M.N., Seal, S., Colvin, J., Briddon, R.W. and Bull, S.E. (2004) East African Cassava Mosaic Zanzibar Virus: A Recombinant Begomovirus Species with a Mild Phenotype. Archives of Virology, 149, 2365-2377. https://doi.org/10.1007/s00705-004-0380-1

[22] Berrie, L.C., Rybicki, E.P. and Rey, M.E.C. (2001) Complete Nucleotide Sequence 
and Host Range of South African Cassava Mosaic Virus: Further Evidence for Recombination amongst Begomoviruses. Journal of General Virology, 82, 53-58. https://doi.org/10.1099/0022-1317-82-1-53

[23] Mabasa, K.G. and Rey, M.E.C. (2007) Epidemiology of Cassava Mosaic Disease and Its Whitefly (Bemisia tabaci) Vector in the Lowveld Region of South Africa. South African Journal of Science, 103, 3.

[24] Ranomenjanahary, S., Rabindran, R. and Robinson, D.J. (2002) Occurrence of Three Distinct Begomoviruses in Cassava in Madagascar. Annals of Applied Biology, 140, 315-318. https://doi.org/10.1111/j.1744-7348.2002.tb00187.x

[25] Adjata, K.D., Muller, E., Peterschmitt, M., Aziadekey, M. and Gumedzoe, Y.M.D. (2008) Incidence of Cassava Viral Diseases and First Identification of East African Cassava Mosaic Virus and Indian Cassava Mosaic Virus by PCR in Cassava (Manihot esculenta Crantz) Fields in Togo. American Journal of Plant Physiology, 3, 73-80. https://doi.org/10.3923/ajpp.2008.73.80

[26] Adjata, K.D., Muller, E., Peterschmitt, M., Traoré, O. and Gumedzoe, Y.M.D. (2009) Molecular Evidence for Association of a Strain of Uganda Variant of East African Cassava Mosaic Virus to Symptom Severity in Cassava (Manihot esculenta Crantz) Fields in Togo. American Journal of Biochemistry and Biotechnology, 5, 196-201. https://doi.org/10.3844/ajbbsp.2009.196.201

[27] Harimalala, M.A., Villemot, J., Hoareau, M., Zinga, I., Ranomenjanahary, S., Reynaud, B., Lefeuvre, P. and Lett, J.M. (2011) Phylogénie et phylogéographie des begomovirus associés à la maladie de la mosaïque du manioc à Madagascar. 13th rencontres de virologie végétale, Aussois, 16-20 janvier 2011, Aussois.

[28] Storey, H.H. (1936) Virus Diseases of East African Plants: VI. A Progress Report Studies of the Diseases of Cassava. East African Scholars Journal of Agriculture and Life Sciences, 2, 34-39.

[29] Nichols, R.F.J. (1950) The Brown Streak Disease of Cassava: Distribution, Climatic Effects and Diagnostic Symptoms. East African Agricultural Journal, 15, 154-160. https://doi.org/10.1080/03670074.1950.11664727

[30] Mangana, S. (2002) Cassava Brown Streak Virus Disease Research in Northern Mozambique. Cassava Brown Streak Virus Disease. Past, Present and Future, Proceedings of an International Workshop, Mombasa, 14-17.

[31] Legg, J.P. and Hillocks, R.J. (2002) Cassava Brown Streak Virus Disease: Past, Present and Future, Proceedings of an International Workshop, Mombasa, Kenya, 27-30 October 2002. 89 p.

[32] Munga, T. and Thresh, J.M. (2002) Incidence of Cassava Mosaic and Cassava Brown Streak Virus Disease in Coastal Kenya. Roots, 8, 12-14.

[33] Bigirimana, S., Barumbanze, P., Ndayihanzamaso, P., Shirima, R. and Legg, J.P. (2011) First Report of Cassava Brown Streak Disease and Associated Ugandan Cassava Brown Streak Virus in Burundi. New Disease Reports, 24, 26. https://doi.org/10.5197/j.2044-0588.2011.024.026

[34] FAO (2011) Cassava Virus on Verge of Epidemic in East Africa: Experts Urge Funding, Swift Action to Protect Staple Food Crop. FAO, Rome. http://www.fao.org/news/story/en/item/94313/icode

[35] Alicai, T., Omongo, C.A., Maruthi, M.N., Hillocks, R.J., Baguma, Y., Kawuki, R., Bua, A., Otim-Nape, G.W. and Colvin, J. (2007) Re-Emergence of Cassava Brown Streak Disease in Uganda. Plant Disease, 91, 24-29. https://doi.org/10.1094/PD-91-0024

[36] Mulimbi, W., Phemba, X., Assumani, B., Kasereka, P., Muyisa, S., Ugentho, H., 
Reeder, R., Legg, J.P., Laurenson, L., Weekes, R. and Thom, F.E.F. (2012) First Report of Ugandan Cassava Brown Streak Virus on Cassava in Democratic Republic of Congo. New Disease Reports, 26, 11. https://doi.org/10.5197/j.2044-0588.2012.026.011

[37] Casinga, C.M., Monde, G. and Legg, J.P. (2018) First Report of Mixed Infection of Cassava Brown Streak Virus and Ugandan Cassava Brown Streak Virus on Cassava in North-Eastern Democratic Republic of Congo. Plant Disease, 103, 166. https://doi.org/10.1094/PDIS-05-18-0836-PDN

[38] Janssens (2001) Le manioc p. 194-218. In: Raemekers, R.H., Ed., Agriculture en Afrique tropicale, DGCD, Bruxelles, 1634.

[39] Hahn, S.K., Isoba, J.C.G. and Ikotun, T. (1989) Resistance Breeding in Root and Tuber Crops at the International Institute of Tropical Agriculture (IITA), Ibadan, Nigeria. Crop Protection, 8, 147-168. https://doi.org/10.1016/0261-2194(89)90022-7

[40] Muyolo, G. (1987) Situation actuelle des principales maladies du manioc au Zaïre et progrès réalisés dans leur contrôle. In: Séminaire sur les maladies et les ravageurs des principales cultures vivrières d'Afrique Centrale, CTA, AGCD, IRAZ, ISABU, Bujumbura, 197-206.

[41] Autrique, A. and Perreaux, D. (1989) Maladies et ravageurs des cultures de la région des grands lacs d'Afrique Centrale. ISABU-AGCD. 232 p.

[42] Hahn, S.K., Terry, E.R. and Leuschner, K. (1980) Breeding Cassava for Resistance to Cassava Mosaic Disease. Euphytica, 29, 673-683.

https://doi.org/10.1007/BF00023215

[43] Night, G., Asiimwe, P., Gashaka, G., Nkezabahizi, D., Legg, J.P., Okao-Okuja, G., Obonyo, R., Nyirahorana, C., Mukakanyana, C., Mukase, F., Munyabarenzi, I. and Mutumwinka, M. (2011) Occurrence and Distribution of Cassava Pests and Diseases in Rwanda. Agriculture, Ecosystems \& Environment, 140, 492-497. https://doi.org/10.1016/j.agee.2011.01.014

[44] Wydra, K. and Verdier, V. (2002) Occurrence of Cassava Diseases in Relation to Environmental, Agronomic and Plant Characteristics. Agriculture, Ecosystems \& Environment, 93, 211-226. https://doi.org/10.1016/S0167-8809(01)00349-8

[45] Hahn, S.K., Terry, E.R. and Leuschner, K. (1980) Breeding Cassava for Resistance to Cassava Mosaic Disease. Euphytica, 29, 673-683. https://doi.org/10.1007/BF00023215

[46] Nukenine, E.N., Hassen, A.T., Dixon, A.G.O. and Fokunang, C.N. (2002) Population Dynamics of Cassava Green Mite, Mononychellus tanajoa (Bondar) (Acari: Tetarnychidae) as Influenced by Varietal Resistance. Pakistan Journal of Biological Sciences, 5, 177-183. https://doi.org/10.3923/pjbs.2002.177.183

[47] Sseruwagi, P., Sserubombwe, W.S., Legg, J.P., Ndunguru, J. and Thresh, J.M. (2004) Methods of Surveying the Incidence and the Severity of Cassava Mosaic Disease and Whitefly Vector Populations on Cassava in Africa: A Review. Virus Research, 100, 129-142. https://doi.org/10.1016/j.virusres.2003.12.021

[48] Winter, S., Koerbler, M., Stein, B., Pietruszka, A., Paape, M. and Butgereitt, A. (2010) Analysis of Cassava Brown Streak Viruses Reveals the Presence of Distinct Virus Species Causing Cassava Brown Streak Disease in East Africa. Journal of General Virology, 91, 1365-1372. https://doi.org/10.1099/vir.0.014688-0

[49] Legg, J.P., Okao-Okuja, G., Mayala, R. and Mahinyuza, J.B. (2001) Spread into Rwanda of the Severe Cassava Mosaic Virus Disease Pandemic and the Associated Uganda Variant of the East African Cassava Mosaic Virus (EACMV-Ug). Plant Pathology, 50, 796. https://doi.org/10.1046/j.1365-3059.2001.00619.x 
[50] Xie, M., Wan, F.H., Chen, Y.H. and Wu, G. (2011) Effects of Temperature on the Growth and Reproduction Characteristics of Bemisia tabaci B-Biotype and Trialeurodes vaporariorum. Journal of Applied Entomology, 135, 252-257. https://doi.org/10.1111/j.1439-0418.2010.01524.x

[51] Tilman, D., Lehman, C.L. and Thomson, K.T. (1997) Plant Diversity and Ecosystem Productivity: Theoretical Considerations. Proceedings of the National Academy of Sciences of the United States of America, 94, 1857-1861.

https://doi.org/10.1073/pnas.94.5.1857

[52] Tilman, D., Cassman, K.G., Matson, P.A., Naylor, R. and Polasky, S. (2002) Agricultural Sustainability and Intensive Production Practices. Nature, 418, 671-677. https://doi.org/10.1038/nature01014

[53] Tilman, D., Reich, P.B. and Knops, J.M.H. (2006) Biodiversity and Ecosystems Stability in a Decade-Long Grassland Experiment. Nature, 44, 629-632.

https://doi.org/10.1038/nature04742

[54] Jones, R.A.C. (2009) Plant Virus Emergence and Evolution: Origins, New Encounter Scenarios, Factors Driving Emergence, Effects of Changing World Conditions, and Prospects for Control. Virus Research, 141, 113-130.

https://doi.org/10.1016/j.virusres.2008.07.028 